\title{
Synthesis, anti-microbial activity and molecular docking studies on triazolylcoumarin derivatives
}

\author{
CHINNADURAI SATHEESHKUMAR ${ }^{\mathrm{a}, \mathrm{b}}$, MAHALINGAM RAVIVARMA $^{\mathrm{a}}$, \\ PANDIAN ARJUN ${ }^{c}$, VAITHIYANATHAN SILAMBARASAN ${ }^{\mathrm{d}}$, NANJIAN RAAMAN ${ }^{\mathrm{c}}$, \\ DEVADASAN VELMURUGAN ${ }^{\mathrm{d}}$, CHANGSIK SONG $^{\mathrm{b}}$ and PERUMAL RAJAKUMAR ${ }^{\mathrm{a}, *}$ \\ ${ }^{a}$ Department of Organic Chemistry, University of Madras, Guindy Campus, Chennai 600025 , \\ Tamilnadu, India \\ ${ }^{b}$ Department of Chemistry, Sungkyunkwan University, Suwon, Gyeonggi 440-746, Republic of Korea \\ ${ }^{\mathrm{c}}$ Centre for Advanced Studies in Botany, Fungal Biotechnology, Natural Products and Plant Tissue Culture \\ Lab, University of Madras, Guindy Campus, Chennai 600 025, Tamilnadu, India \\ ${ }^{\mathrm{d}}$ Center of Advanced Study in Crystallography and Biophysics, University of Madras, Guindy Campus, \\ Chennai 600 025, Tamilnadu, India \\ e-mail: perumalrajakumar@gmail.com
}

MS received 5 April 2014; revised 22 August 2014; accepted 13 October 2014

\begin{abstract}
A series of triazolylcoumarins was synthesized by the cycloaddition of acetylenic derivatives to azide in the presence of $\mathrm{Cu}(\mathrm{I})$ catalyst at room temperature. All the synthesized compounds were evaluated for their anti-microbial activity against Gram-positive (B. subtilis and S. aureus), Gram-negative bacteria ( $K$. pneumonia and P. vulgaris) and human pathogenic fungi (C. tropicalis and C. krusei), with tetracycline and fluconazole as standards for anti-microbial and anti-fungal activity. Triazolylcoumarins exhibit anti-microbial activity against all the tested pathogens, which is further supported by molecular docking studies.
\end{abstract}

Keywords. Coumarin; 1,2,3-triazole; anti-microbial; molecular docking and ADMET.

\section{Introduction}

During the last decade, due to the increase in the number of immuno-compromised hosts, the incidence of systemic microbial infection has been increasing drastically. Further, most of the microorganisms develop resistance over a period of time against available drugs. Hence, the available anti-microbial medicines are either less effective or ineffective. There is a need to search for alternative antimicrobial agents. Coumarin, known as 1,2-benzopyrone, occurs naturally in plants, notably in high concentration in the tonka bean, vanilla grass, sweet woodruff and mullein. Coumarin and its derivatives attract great attention due to their wide range of biological activities such as anti-cancer, ${ }^{1}$ antimicrobial, ${ }^{2}$ anti-HIV, ${ }^{3}$ antioxidant, ${ }^{4}$ anti-viral, ${ }^{5}$ antiinflammatory, ${ }^{6}$ anti-coagulant ${ }^{7}$ and as inhibitors of lipoxygenase ${ }^{8}$ and cyclooxygenase. ${ }^{9}$

Click chemistry ${ }^{10-12}$ has emerged as a reliable approach for the stereo selective synthesis of 1,2,3triazole with desired properties. Cycloaddition of azide to alkyne in the presence of copper sulphate and sodium ascorbate to give 1,2,3-triazole has drawn considerable

*For correspondence attention due to its wide range of biological activi$\operatorname{ties}^{13,14}$ as well as in material applications. ${ }^{15}$ Click reaction is unique due to high yield and there is no need for a protection or deprotection protocol. Further, 1,2,3triazole ring system is highly stable under hydrolytic as well as under reductive and oxidative conditions. Recent synthesis have focused on the design of triazole based coumarin compounds using CuAAC reaction. ${ }^{16,17}$

In fact, compounds with the combination of coumarin with triazole systems will be interesting and such molecules may have better bioactivity than coumarin itself. Hence, the aim of the present investigation is to synthesize and characterize triazole-based coumarin derivatives 1-8 (figure 1) and screen them for their in vitro anti-microbial activity. Molecular docking and Absorption, Distribution, Metabolism, Excretion and Toxicity (ADMET) properties of the synthesized coumarin derivatives have also been studied.

\section{Experimental}

\subsection{General}

All melting points were determined using a Toshniwal melting point apparatus by the open capillary tube 

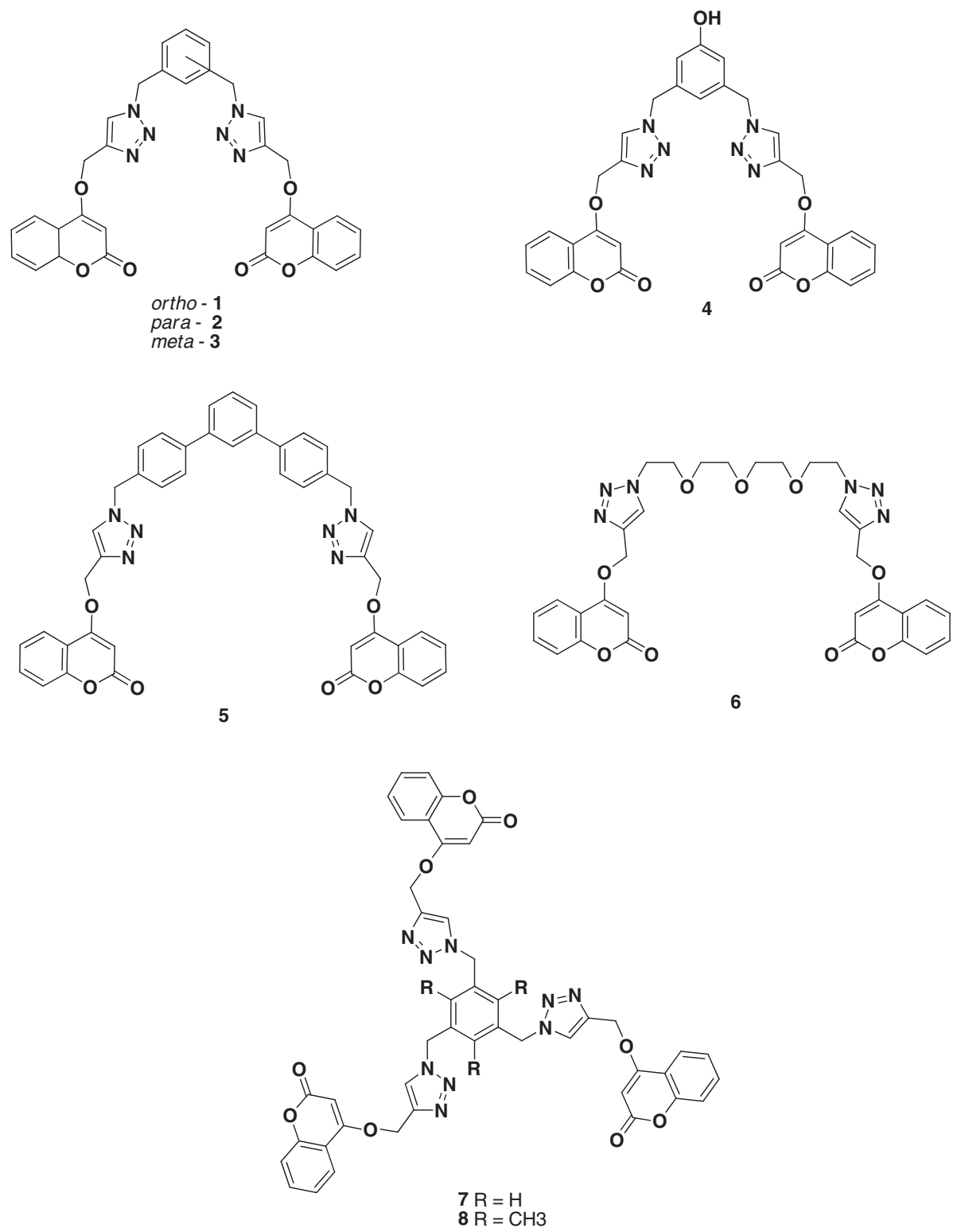

Figure 1. Molecular structures of triazolylcoumarins 1-8.

method and are uncorrected. ${ }^{1} \mathrm{H}$ NMR and ${ }^{13} \mathrm{C}$ NMR spectra were recorded on a Bruker $300 \mathrm{MHz}$ instrument. The mass spectra (ESI-electron spray ionization) were recorded on a Perkin Elmer Sciex mass spectrophotometer. Elemental analyses were carried out using a Perkin Elmer CHNS 2400 instrument. Column chromatography was performed on silica gel (ACME, 100200 mesh). Routine monitoring of the reaction was made using thin layer chromatography developed on glass plates coated with silica gel-G (ACME) of $25 \mathrm{~mm}$ thickness and visualized with iodine. All the reagents and solvents employed were of the best grade available and used without further purification.
2.2 General procedure for the synthesis of di and tri azides from di and tri bromides (18-25)

To corresponding di or tri bromides $(1 \mathrm{mmol})$ dissolved in dry DMF $(20 \mathrm{~mL})$, sodium azide $(1.5 \mathrm{mmol})$ was added and stirring was continued at room temperature for $12 \mathrm{~h}$. The reaction mixture was poured into water $(30 \mathrm{~mL})$ and extracted with $\mathrm{CHCl}_{3}(3 \times 100 \mathrm{~mL})$. The organic layer was washed with water $(100 \mathrm{~mL})$ and saturated $\mathrm{NaCl}(3 \times 100 \mathrm{~mL})$, dried $\left(\mathrm{MgSO}_{4}\right)$. Solvent was evaporated under reduced pressure to afford the crude product, which was purified by column chromatography $\left(\mathrm{SiO}_{2}\right)$. 


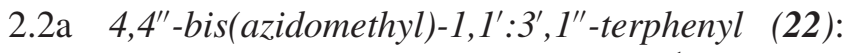
Yield $0.25 \mathrm{~g}(81 \%)$; M.p. $96-98^{\circ} \mathrm{C} ;{ }^{1} \mathrm{H}$ NMR: $\left(300 \mathrm{MHz}, \mathrm{CDCl}_{3}\right) \delta 2.32(\mathrm{~s}, 4 \mathrm{H}), 7.12(\mathrm{~s}, 1 \mathrm{H}), 7.14$ $(\mathrm{d}, 2 \mathrm{H}), 7.16(\mathrm{~s}, 4 \mathrm{H}), 7.29(\mathrm{~s}, 4 \mathrm{H}), 7.31(\mathrm{~s}, 1 \mathrm{H}) .{ }^{13} \mathrm{C}$ NMR: $\left(75 \mathrm{MHz}, \mathrm{CDCl}_{3}\right) \delta 54.5,128.4,128.5,128.8$, 129.2, 129.8, 137.2, 145.5, 148.1. HRMS m/z $=341.40$ $(\mathrm{M}+1)^{+}$; Elemental Anal. Calcd. for $\mathrm{C}_{20} \mathrm{H}_{16} \mathrm{~N}_{6}$ : C, 70.57; H,4.74; N, 24.69; Found C, 70.27; H, 4.86; N, 24.31. Elemental Analysis: C, 70.57; H, 4.74; N, 24.69

\subsection{General procedure for the $\mathrm{Cu}(\mathrm{I})$-catalyzed Huisgen click reaction (1-8)}

Acetylenic derivative $(1.0 \mathrm{mmol})$ was added to azide $(0.5 \mathrm{mmol})$ in a mixture of THF and water (1:1) solution. Sodium ascorbate $(10 \mathrm{~mol} \%)$ was added to the reaction mixture, followed by the addition of $\mathrm{CuSO}_{4} .5 \mathrm{H}_{2} \mathrm{O}(5 \mathrm{~mol} \%)$. The reaction mixture was stirred overnight at room temperature and after completion of the reaction the solvent was evaporated under reduced pressure and the crude product was dissolved in ethyl acetate $(100 \mathrm{~mL})$, washed with water $(100 \mathrm{~mL})$, brine solution $(50 \mathrm{~mL})$ and dried $\left(\mathrm{Na}_{2} \mathrm{SO}_{4}\right)$. Evaporation of the solvent afforded a residue which was purified by column chromatography (silica gel) with $\mathrm{CHCl}_{3} / \mathrm{MeOH}$ (9:1) as an eluent to give the corresponding triazolylcoumarins.

$2.3 \mathrm{a} \quad 4-((1-(2-((4-)((2-0 x o-4 a, 8 a-d i h y d r o-2 H-c h r o m e n-$ 4-yl)oxy)methyl)-1H-1,2,3-triazol-1-yl)methyl)benzyl)1H-1,2,3-triazol-4-yl)methoxy)-2H-chromen-2-one (1): Yield $0.33 \mathrm{~g}$ (70\%); M.p. $234-236^{\circ} \mathrm{C} ;{ }^{1} \mathrm{H}$ NMR $\left(300 \mathrm{MHz}, \mathrm{DMSO}-d_{6}\right) \delta 5.43(\mathrm{~s}, 4 \mathrm{H}), 5.91(\mathrm{~s}, 4 \mathrm{H}), 6.15$ (s, 2H), 7.19-7.22 (m, 2H), 7.30-7.41 (m, 6H), 7.64 (t, $2 \mathrm{H}, J=7.8 \mathrm{~Hz}), 7.75(\mathrm{~d}, 2 \mathrm{H}, J=7.8 \mathrm{~Hz}), 8.44(\mathrm{~s}$, $2 \mathrm{H}) ;{ }^{13} \mathrm{C}$ NMR (75 MHz, DMSO- $\left.d_{6}\right) \delta 50.0,62.7,91.3$, $115.0,116.4,122.9,124.2,125.6,128.9,129.3,132.8$, 134.1, 141.3, 152.7, 161.5, 164.3; MALDI-TOF-MS $\mathrm{m} / \mathrm{z}=611.39(\mathrm{M}+\mathrm{Na})^{+}, 627.39(\mathrm{M}+\mathrm{K})^{+}$; Elemental Anal. Calcd. for $\mathrm{C}_{32} \mathrm{H}_{24} \mathrm{~N}_{6} \mathrm{O}_{6}: \mathrm{C}, 65.30 ; \mathrm{H}, 4.11 ; \mathrm{N}$, 14.28; Found C, 65.26; H, 4.12; N, 14.34.

$2.3 \mathrm{~b}$ 4-((1-(4-((4-)((2-oxo-4a,8a-dihydro-2H-chromen4-yl)oxy)methyl)-1H-1,2,3-triazol-1-yl)methyl)benzyl)1H-1,2,3-triazol-4-yl)methoxy)-2H-chromen-2-one (2): Yield $0.31 \mathrm{~g}(66 \%)$; M.p. $248-250{ }^{\circ} \mathrm{C} ;{ }^{1} \mathrm{H}$ NMR $\left(300 \mathrm{MHz}, \mathrm{DMSO}-d_{6}\right) \delta 5.41(\mathrm{~s}, 4 \mathrm{H}), 5.65(\mathrm{~s}, 4 \mathrm{H}), 6.15$ (s, 2H), 7.30-7.42 (m, 8H), $7.66(\mathrm{t}, 2 \mathrm{H}, J=7.5 \mathrm{~Hz})$, $7.73(\mathrm{~d}, 2 \mathrm{H}, J=7.8 \mathrm{~Hz}), 8.44(\mathrm{~s}, 2 \mathrm{H}) ;{ }^{13} \mathrm{C} \mathrm{NMR}$ $\left(75 \mathrm{MHz}, \mathrm{DMSO}-d_{6}\right) \delta 52.5,62.7,91.3,115.0,116.4$, $122.8,124.2,125.3,128.5,132.8,135.9,141.3,152.7$, 161.5, 164.3; HRMS m/z $=591(\mathrm{M}+1)^{+}$; Elemental
Anal. Calcd. for $\mathrm{C}_{32} \mathrm{H}_{24} \mathrm{~N}_{6} \mathrm{O}_{6}: \mathrm{C}, 65.30 ; \mathrm{H}, 4.11 ; \mathrm{N}$, 14.28; Found C, 65.28; H, 4.12; N, 14.31 .

$2.3 \mathrm{c} \quad 4-((1-(3-)(4-(((2-o x o-4 a, 8 a-d i h y d r o-2 H-c h r o m e n-$ 4-yl)oxy)methyl)-1H-1,2,3-triazol-1-yl)methyl)benzyl)1H-1,2,3-triazol-4-yl)methoxy)-2H-chromen-2-one (3): Yield $0.34 \mathrm{~g}$ (72\%); M.p. $213-215^{\circ} \mathrm{C}$; ${ }^{1} \mathrm{H}$ NMR $\left(300 \mathrm{MHz}, \mathrm{DMSO}-d_{6}\right) \delta 5.40(\mathrm{~s}, 4 \mathrm{H}), 5.67(\mathrm{~s}, 4 \mathrm{H}), 6.12$ (s, 2H), 7.31-7.45 (m, 8H), $7.64(\mathrm{t}, 2 \mathrm{H}, J=7.8 \mathrm{~Hz})$, $7.72(\mathrm{~d}, J=7.8 \mathrm{~Hz}, 2 \mathrm{H}), 8.46(\mathrm{~s}, 2 \mathrm{H}) ;{ }^{13} \mathrm{C} \mathrm{NMR}$ $\left(75 \mathrm{MHz}, \mathrm{DMSO}-d_{6}\right) \delta 52.6,62.7,91.3,114.9,116.4$, $122.8,124.2$, 125.4, 127.5, 127.9, 129.3, 132.8, 136.5, 141.2, 152.7, 161.5, 164.3; MALDI-TOF-MS m/z = $611.49(\mathrm{M}+\mathrm{Na})^{+}, 627.49(\mathrm{M}+\mathrm{K})^{+}$; Elemental Anal. Calcd. for $\mathrm{C}_{32} \mathrm{H}_{24} \mathrm{~N}_{6} \mathrm{O}_{6}$ : C, 65.30; H,4.11; N, 14.28; Found C, 65.35; H, 4.16; N, 14.29.

$2.3 \mathrm{~d} \quad 4,4^{\prime}-\left(\left(\left(1,1^{\prime}-((5-h y d r o x y-1,3-p h e n y l e n e) b i s(m e t h y-\right.\right.\right.$ lene))bis(1H-1,2,3-triazole-4,1-diyl))bis(methylene))bis (oxy))bis(2H-chromen-2-one) (4): Yield $0.42 \mathrm{~g}(71 \%)$; M.p. $237-239^{\circ} \mathrm{C} ;{ }^{1} \mathrm{H}$ NMR $\left(300 \mathrm{MHz}, \mathrm{DMSO}-d_{6}\right) \delta$ $5.40(\mathrm{~s}, 4 \mathrm{H}), 5.57(\mathrm{~s}, 4 \mathrm{H}), 6.14(\mathrm{~s}, 2 \mathrm{H}), 6.66(\mathrm{~s}, 2 \mathrm{H})$, $6.76(\mathrm{~s}, 1 \mathrm{H}), 7.31-7.41(\mathrm{~m}, 4 \mathrm{H}), 7.64(\mathrm{t}, 2 \mathrm{H}, J=7.2$ $\mathrm{Hz}), 7.73$ (d, 2H, $J=7.5 \mathrm{~Hz}), 8.44(\mathrm{~s}, 2 \mathrm{H}), 9.77$ (s, $1 \mathrm{H}) ;{ }^{13} \mathrm{C}$ NMR (75 MHz, DMSO- $\left.d_{6}\right) \delta 52.6,62.7,91.2$, $114.5,114.9,116.4,117.8,122.8,124.2,125.4,132.8$, 137.7, 141.2, 152.7, 157.9, 161.6, 164.3; MALDITOF-MS m/z $=627.72(\mathrm{M}+\mathrm{Na})^{+}, 643.71(\mathrm{M}+\mathrm{K})^{+}$; Elemental Anal. Calcd. for $\mathrm{C}_{32} \mathrm{H}_{24} \mathrm{~N}_{6} \mathrm{O}_{7}$ : C, 63.57; H,4.00; N, 13.90; Found C, 63.58; H, 4.00; N, 13.88 .

$2.3 \mathrm{e} \quad 4,4^{\prime}-\left(\left(\left(1,1^{\prime}-\left(1,1^{\prime}: 3^{\prime}, 1^{\prime \prime}\right.\right.\right.\right.$-terphenyl-4,4'-diylbis(methylene))bis(1H-1,2,3-triazole-4,1-diyl))bis(methylene)) bis(oxy))bis(2H-chromen-2-one) (5): Yield $0.50 \mathrm{~g}$ (76\%); M.p. 222-224 ${ }^{\circ}$; ${ }^{1} \mathrm{H}$ NMR (300 MHz, DMSO$\left.d_{6}\right) \delta 5.45(\mathrm{~s}, 4 \mathrm{H}), 5.73(\mathrm{~s}, 4 \mathrm{H}), 6.18(\mathrm{~s}, 2 \mathrm{H}), 7.20-7.27$ $(\mathrm{m}, 8 \mathrm{H}), 7.38-7.42(\mathrm{~m}, 8 \mathrm{H}), 7.65(\mathrm{~d}, 2 \mathrm{H}, J=7.5$ $\mathrm{Hz}), 7.76(\mathrm{~d}, 2 \mathrm{H}, J=7.8 \mathrm{~Hz}), 8.54(\mathrm{~s}, 2 \mathrm{H}) ;{ }^{13} \mathrm{C} \mathrm{NMR}$ $\left(75 \mathrm{MHz}, \mathrm{DMSO}-d_{6}\right) \delta 52.6,62.8,91.3,115.0,116.4$, $122.9,124.2,125.5,127.5,128.5,129.0,129.6,135.1$, 136,7, 141.3, 142.2, 146.9, 152.7, 161.5, 164.3; HRMS $\mathrm{m} / \mathrm{z}=741.59(\mathrm{M}+1)^{+}$; Elemental Anal. Calcd. for $\mathrm{C}_{44} \mathrm{H}_{32} \mathrm{~N}_{6} \mathrm{O}_{6}: \mathrm{C}, 71.34 ; \mathrm{H}, 4.35 ; \mathrm{N}, 11.35$; Found $\mathrm{C}$, 71.35; H, 4.39; N, 11.31 .

$2.3 \mathrm{f} \quad 4,4^{\prime}-\left(\left(\left(1,1^{\prime}-1((\right.\right.\right.$ oxybis (ethane-2,1-diyl))bis(oxy))bis (ethane-2,1-diyl))bis(1H-1,2,3-triazole-4,1-diyl))bis(methylene))bis(oxy))bis(2H-chromen-2-one) (6): Yield $0.30 \mathrm{~g}$ (75\%); M.p. $138-140^{\circ} \mathrm{C} ;{ }^{1} \mathrm{H}$ NMR $(300 \mathrm{MHz}$, DMSO- $\left.d_{6}\right) \delta 3.39-3.45(\mathrm{~m}, 4 \mathrm{H}), 3.48-3.50(\mathrm{~m}, 4 \mathrm{H})$, $3.83(\mathrm{t}, 4 \mathrm{H}, J=4.8 \mathrm{~Hz}), 4.57(\mathrm{t}, 4 \mathrm{H}, J=4.8 \mathrm{~Hz})$, 
$5.42(\mathrm{~s}, 4 \mathrm{H}), 6.17(\mathrm{~s}, 2 \mathrm{H}), 7.31(\mathrm{t}, 2 \mathrm{H}, J=7.5 \mathrm{~Hz})$, $7.39(\mathrm{~d}, 2 \mathrm{H}, J=8.1 \mathrm{~Hz}), 7.64(\mathrm{t}, 2 \mathrm{H}, J=7.5 \mathrm{~Hz})$, $7.71(\mathrm{~d}, 2 \mathrm{H}, J=7.8 \mathrm{~Hz}), 8.35(\mathrm{~s}, 2 \mathrm{H}) ;{ }^{13} \mathrm{C} \mathrm{NMR}$ $\left(75 \mathrm{MHz}, \mathrm{DMSO}-d_{6}\right) \delta$ 49.5, 62.7, 68.6, 69.5 (2C), 91.3, 115.0, 116.4, 122.7, 124.1, 125.6, 132.7, 140.8, 152.7, 161.5, 164.3; MALDI-TOF-MS m/z $=667.52$ $(\mathrm{M}+\mathrm{Na})^{+}, 683.52(\mathrm{M}+\mathrm{K})^{+}$; Elemental Anal. Calcd. for $\mathrm{C}_{32} \mathrm{H}_{32} \mathrm{~N}_{6} \mathrm{O}_{9}$ : C, 59.62; H,5.00; N, 13.04; Found C, $59.60 ; \mathrm{H}, 5.01 ; \mathrm{N}, 13.00$.

$2.3 \mathrm{~g} \quad 4,4^{\prime}, 4^{\prime \prime}-\left(\left(\left(1,1^{\prime}, 1^{\prime \prime}\right.\right.\right.$-(benzene-1,3,5-triyltris(methylene))tris(1H-1,2,3-triazole-4,1-diyl))tris(methylene))tris (oxy))tris(2H-chromen-2-one) (7): Yield 0.51 g (74\%); M.p. $232-234^{\circ} \mathrm{C} ;{ }^{1} \mathrm{H}$ NMR $\left(300 \mathrm{MHz}, \mathrm{DMSO}-d_{6}\right) \delta$ $5.37(\mathrm{~s}, 6 \mathrm{H}), 5.67(\mathrm{~s}, 6 \mathrm{H}), 6.08(\mathrm{~s}, 3 \mathrm{H}), 7.29-7.38(\mathrm{~m}$, $9 \mathrm{H}), 7.62(\mathrm{t}, 3 \mathrm{H}, J=7.8 \mathrm{~Hz}), 7.72(\mathrm{~d}, 2 \mathrm{H}, J=7.8$ $\mathrm{Hz}), 8.46(\mathrm{~s}, 3 \mathrm{H}) ;{ }^{13} \mathrm{C}$ NMR $\left(75 \mathrm{MHz}, \mathrm{DMSO}-d_{6}\right) \delta$ $52.4,62.7,91.2,114.9,116.4,122.9,124.1,125.4$, 127.4, 132.7, 137.2, 141.2, 152.7, 161.5, 164.2; HRMS $\mathrm{m} / \mathrm{z}=845.3(\mathrm{M}+1)^{+}$; Elemental Anal. Calcd. for $\mathrm{C}_{45} \mathrm{H}_{33} \mathrm{~N}_{9} \mathrm{O}_{9}$ : C, 64.05; H,3.94; N, 14.94; Found $\mathrm{C}$, 64.07; H, 3.89; N, 14.98 .

$2.3 \mathrm{~h} \quad 4,4^{\prime}, 4^{\prime \prime}-\left(\left(\left(1,1^{\prime}, 1^{\prime \prime}-((2,4,6-\right.\right.\right.$ trimethylbenzene-1,3,5triyl)tris(methylene))tris(1H-1,2,3-triazole-4,1-diyl))tris (methylene))tris(oxy))tris(2H-chromen-2-one) (8): Yield 0.26 g (70\%); M.p. $102-104^{\circ} \mathrm{C}$; ${ }^{1} \mathrm{H}$ NMR $(300 \mathrm{MHz}$, $\left.\mathrm{CDCl}_{3}\right) \delta 2.39(\mathrm{~s}, 9 \mathrm{H}), 5.28(\mathrm{~s}, 6 \mathrm{H}), 5.66(\mathrm{~s}, 6 \mathrm{H}), 5.82$ (s, 3H); 7.25-7.28 (m, 6H), 7.48-7.55 (m, 6H), $7.73(\mathrm{~d}$, $3 \mathrm{H}, J=7.8 \mathrm{~Hz}) ;{ }^{13} \mathrm{C} \mathrm{NMR}\left(75 \mathrm{MHz}, \mathrm{CDCl}_{3}\right) \delta 20.1$, $48.8,62.5,91.1,115.4,116.7,122.9,123.9,129.2$, 131.8, 139.5, 141.3, 153.3, 164.9; HRMS m/z = 886.7 $(\mathrm{M}+1)^{+}$; Elemental Anal. Calcd. for $\mathrm{C}_{48} \mathrm{H}_{39} \mathrm{~N}_{9} \mathrm{O}_{9}$ : C, 65.08; H,4.44; N, 14.23; Found C, 65.10; H, 4.41; N, 14.25 .

\subsection{Anti-bacterial activity}

The in vitro antibacterial activity of the triazole-based coumarin derivatives 1-8 was determined by the well diffusion method. ${ }^{18}$ The Muller Hinton Agar (MHA) medium was used for the preparation of the plates. The medium was poured onto sterile petri dishes of $90 \mathrm{~mm}$ diameter. The agar was allowed to set at ambient temperature. Fresh human pathogenic bacterial cultures inoculated into the Muller Hinton Broth (MHB) of two Gram-positive bacteria, Bacillus subtilis (MTCC-441) and Staphylococcus aureus (MTCC-98) and two Gram-negative bacteria, Klebsiella pneumoniae (MTCC-109) and Proteus vulgaris (MTCC-742) were spread on the surface of the MHA plate with swabs. They were allowed to incubate; after incubation, using a sterile cork ( $9 \mathrm{~mm}$ diam) borer, wells were cut from the MHA in the petri dishes. The compounds were weighed $(5 \mathrm{mg} / \mathrm{mL})$ and dissolved in dimethyl sulfoxide (DMSO). Different volumes of $25 \mu \mathrm{L}, 50 \mu \mathrm{L}$ and $75 \mu \mathrm{L}$ test solution were poured into the wells using a sterile micropipette. The inoculated plates were initially incubated for $15 \mathrm{~min}$ at room temperature and then they were incubated at $37^{\circ} \mathrm{C}$ for $24 \mathrm{~h}$. Turbidity was adjusted with a sterile broth so as to correspond to $0.5 \mathrm{McFar}-$ land standards. Inhibition zones were recorded as the diameter of the growth free zones, including the diameter of the well in $\mathrm{mm}$ at the end of the incubation period. The percentage of inhibition was calculated by the formula: $\%$ of inhibition $=\{\mathrm{I}$ (Diameter of the inhibition zone)/90 (Diameter of the petri-plate in $\mathrm{mm}$ ) $\} \times 100$, where $\mathrm{I}=$ Zone of inhibition.

\subsection{Anti-fungal activity}

Anti-fungal activity of compounds 1-8 was determined, ${ }^{19}$ Sabouraud Dextrose Agar (SDA) medium was used for the preparation of plates. The anti-fungal activities of compounds 1-8 were tested against two human pathogenic fungi Candida tropicalis and Candida krusei. The medium was poured into sterile petriplates of $90 \mathrm{~mm}$ diameter. The agar was allowed to set at ambient temperature. Fresh fungal culture inoculated into the Sabouraud Dextrose Broth (SDB) was spread on the surface of the SDA plate with the swab. After incubation, the SDA plates were allowed pre-incubation for $10 \mathrm{~min}$, after that using the cork borer ( $9 \mathrm{~mm}$ diameter) well was cut on the agar plate. The compounds were weighed $(5 \mathrm{mg} / \mathrm{mL})$ and dissolved in dimethyl sulfoxide (DMSO). The solution was poured $(25 \mu \mathrm{L}, 50 \mu \mathrm{L}$ and $75 \mu \mathrm{L}$ ) using a sterile micropipette. The inoculated plates were initially incubated for $15 \mathrm{~min}$ at room temperature and then they were incubated at $37^{\circ} \mathrm{C}$ for $24 \mathrm{~h}$. Then, the plates were examined for the growth inhibition zone. Inhibition zones were measured as the diameter of the growth free zones in mm including the diameter of the well at the end of the incubation period.

The percentage of inhibition was calculated by the formula: $\%$ of inhibition $=\{\mathrm{I}$ (Diameter of the inhibition zone)/90 (Diameter of the petri-plate in $\mathrm{mm}$ ) $\} \times$ 100 , where $\mathrm{I}=$ Zone of inhibition.

\subsection{Docking studies}

The protein in complex with simocyclinone (PDB ID: 2Y3P) was used as the template for molecular docking studies. GLIDE 9.5 and IFD script from Schrödinger, LLC (New York) was employed as our primary docking engine. ${ }^{20} \mathrm{~A}$ hierarchical search protocol was utilized by 
the docking algorithm of the GLIDE program. The scoring function, called the GLIDE score, for computing the binding affinity based Chem-Score function ${ }^{20}$ is used. OPLS is the molecular mechanism whose potential energy function was used throughout the calculations. The extra precision mode of GLIDE, which has higher penalties for unfavourable and unphysical interactions, was used for docking. Computations were carried out on a Linux system with CentOS-5 computer platform. The pictures were generated using LIGPLOT. ${ }^{21}$

\section{Results and Discussion}

The reaction of di and tri bromides 10-17 with sodium azide at room temperature afforded di and tri azides ${ }^{22}$ 18-25 in good yields respectively (scheme 1).

The reaction of propargyloxy coumarin 9 with 0.5 equivalents of azides 18-23 under the click reaction conditions of $\mathrm{CuSO}_{4} .5 \mathrm{H}_{2} \mathrm{O}(5 \mathrm{~mol} \%)$ and sodium ascorbate $(10 \mathrm{~mol} \%)$, in a mixture of water-THF $(1: 1)$ at room temperature gave the triazolylcoumarin 1-6 in good yield (scheme 2).

The ${ }^{1} \mathrm{H}$ NMR spectrum of compound 1 displayed two singlets at $\delta 5.43$ and $\delta 5.91$ for $N$-methylene and $O$ methylene protons, respectively in addition to aromatic proton signals. The ${ }^{13} \mathrm{C}$ NMR spectrum of compound $\mathbf{1}$ displayed singlets at $\delta 50.0$ and $\delta 62.7$ for $N$-methylene and $O$-methylene carbons, respectively, along with aromatic carbon signals. The appearance of a molecular ion peak at $\mathrm{m} / \mathrm{z} 611.39$ confirmed the structure of the triazolylcoumarin 1. Similarly, the structure of the compounds 2-6 was also confirmed from the spectral and analytical data.

Further, the reaction of propargyloxy coumarin 9 with 0.33 equivalents of azides $\mathbf{2 4}$ and $\mathbf{2 5}$ under $\mathrm{Cu}$ (I) catalyzed click reaction conditions, offered the compound $\mathbf{7}$ and 8 in $74 \%$ and $70 \%$ yields, respectively (scheme 2). Compound 7 in ${ }^{1} \mathrm{H}$ NMR spectrum displayed two singlets at $\delta 5.37$ and $\delta 5.67$ for $N$ methylene and $O$-methylene protons, respectively in addition to aromatic proton signals. The ${ }^{13} \mathrm{C}$ NMR spectrum showed the carbon signals at $\delta 52.4$ and $\delta 62.7$ for $\mathrm{N}$-methylene and $O$-methylene carbons, respectively along with the signals for aromatic carbons. Similarly, the structure of the compound $\mathbf{8}$ was also confirmed from spectral and analytical data.

The synthesized compounds $\mathbf{1 - 8}$ were evaluated for in vitro anti-bacterial and anti-fungal activity against two Gram-positive bacteria, B. subtilis and S. aureus, two Gram-negative bacteria, K. pneumoniae and $P$. vulgaris and two fungal pathogens, $C$. tropicalis and $C$. krusei using the well diffusion method. Standard antibacterial and anti-fungal drugs, viz., tetracycline and fluconazole were also screened for comparison. The inhibition percentages of the various microbial strains are shown in table 1. All the triazole based coumarin derivatives showed various levels of inhibitory effects against human pathogenic bacteria and fungi. The anti-microbial activities of these compounds were dose dependent and found to be significant at $75 \mu \mathrm{L}$ addition.

The synthesized triazolylcoumarins; compound $\mathbf{1}$ to $\mathbf{8}$ were screened for anti-bacterial and anti-fungal activity against human pathogens. Compound $\mathbf{1}$ showed antibacterial activity against Gram-positive bacterium; $S$. aureus, Gram-negative bacteria, K. pneumonia, P. vulgaris, anti-fungal activity against $C$. tropicalis and $C$. krusei. Compound $\mathbf{1}$ didn't show any activity against Gram-positive bacterium; B. subtilis. Compounds 2 and 3 showed activity against $K$. pneumonia, $P$. vulgaris, C. tropicalis and C. krusei but didn't show any activity against $B$. subtilis and $S$. aureus. Compound $\mathbf{5}$ showed activity against $B$. subtilis, $S$. aureus, $P$. vulgaris, $C$. tropicalis and C. krusei, but didn't show activity against



Scheme 1. i) $\mathrm{NaN}_{3}$, DMF, rt., 12 h, 18 (84\%), 19 (82\%), 20 (81\%), 21 (80\%), 22 (81\%), 23 (89\%), 24 $(87 \%)$ and $25(89 \%)$. 

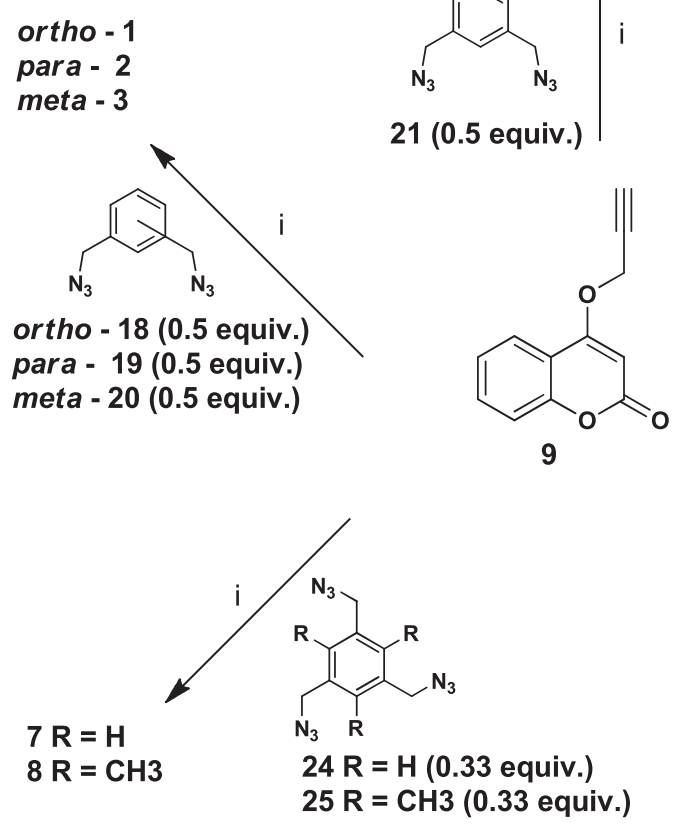
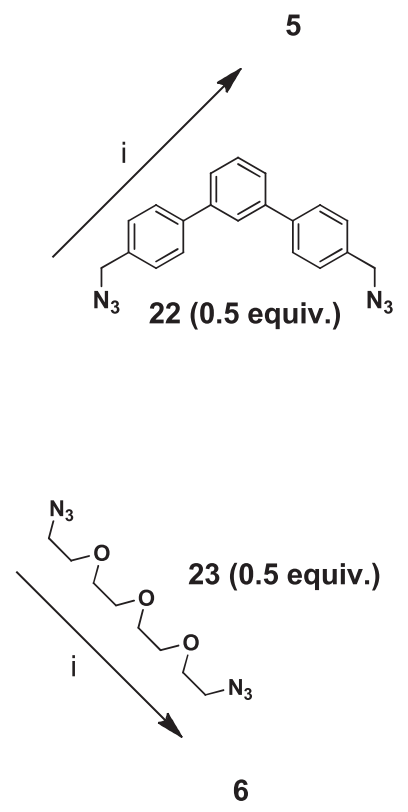

Scheme 2. i) $\mathrm{CuSO}_{4} .5 \mathrm{H}_{2} \mathrm{O}(5 \mathrm{~mol} \%)$, sodium ascorbate $(10 \mathrm{~mol} \%), \mathrm{H}_{2} \mathrm{O}-$ THF (1:1, v/v), rt., 10 h, $1(70 \%), 2(66 \%), 3(72 \%), \mathbf{4}(71 \%), \mathbf{5}(76 \%), \mathbf{6}(75 \%)$, $7(74 \%)$ and $8(70 \%)$.

Table 1. Anti-microbial activity of triazolylcoumarins 1-8 (values given are mean values with triplicate $(\mathrm{n}=3)$.

\begin{tabular}{|c|c|c|c|c|c|c|c|c|c|c|c|c|c|c|c|c|c|c|}
\hline \multirow[b]{3}{*}{ Microbial strains } & \multicolumn{18}{|c|}{ Well diffusion method (Zone of inhibition (dia. in $\mathrm{mm}$ ) } \\
\hline & \multicolumn{2}{|c|}{ Standard $^{\mathrm{a}}$} & \multicolumn{2}{|r|}{1} & \multicolumn{2}{|c|}{2} & \multicolumn{2}{|c|}{3} & \multicolumn{2}{|r|}{4} & \multicolumn{2}{|c|}{5} & \multicolumn{2}{|r|}{6} & \multicolumn{2}{|r|}{7} & \multicolumn{2}{|r|}{8} \\
\hline & $\mathrm{I}^{\mathrm{b}}$ & $\mathrm{I} \%^{\mathrm{c}}$ & I & $\mathrm{I} \%$ & $\mathrm{I}$ & $\mathrm{I} \%$ & I & $\mathrm{I} \%$ & I & $\mathrm{I} \%$ & $\mathrm{I}$ & $\mathrm{I} \%$ & I & $\mathrm{I} \%$ & I & $\mathrm{I} \%$ & I & $\mathrm{I} \%$ \\
\hline B. subtilis & 25 & 26.66 & NI & NI & NI & NI & NI & NI & 12 & 13.33 & 12 & 13.33 & 11 & 12.22 & 15 & 16.66 & 14 & 15.55 \\
\hline S. $a$ & 22 & 23.33 & 12 & 13.33 & NI & NI & NI & NI & 12 & 13.33 & 12 & 13.33 & 12 & 13 & NI & NI & NI & NI \\
\hline umoniae & $\mathrm{NI}^{\mathrm{d}}$ & NI & 14 & 15.55 & 15 & 16.66 & 13 & 14.44 & 19 & 20 & NI & NI & 16 & 17.77 & 17 & 18.88 & 17 & 18.88 \\
\hline P. $m$ & 20 & 21.11 & 14 & 15.55 & 12 & 13.33 & NI & NI & 13 & 14.44 & 12 & 13.33 & 12 & 13.33 & 12 & 13.33 & 13 & 14.44 \\
\hline C. krusei & NI & NI & 15 & 16.66 & 15 & 16.66 & 14 & 15.55 & 15 & 16.66 & 14 & 15.55 & 15 & 16.66 & 12 & 13.33 & 13 & 14.44 \\
\hline C. tropical & NI & NI & 15 & 16.66 & 15 & 16.66 & 14 & 15.55 & 19 & 20 & 12 & 13.33 & 15 & 16.66 & 16 & 17.77 & 14 & 15.55 \\
\hline
\end{tabular}

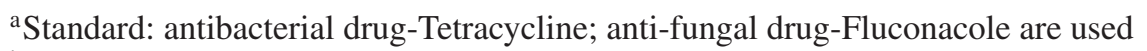

b Zone of inhibition

${ }^{\mathrm{c}}$ Percentage of zone of inhibition

${ }^{\mathrm{d}}$ No Inhibition

K. pneumonia. Compounds $\mathbf{7}$ and $\mathbf{8}$ showed activity against B. subtilis, K. pneumonia, P. vulgaris, C. tropicalis and $C$. krusei, but didn't show activity against $S$. aureus. Tetracycline and fluconazole were used as internal standard for anti-bacterial activity and fungal activity, respectively.

Compounds 4 and $\mathbf{6}$ showed anti-bacterial activity against $B$. subtilis, $S$. aureus, $K$. pneumonia, $P$. vulgaris and anti-fungal activity against $C$. tropicalis and $C$. krusei. Compared to all the compounds $\mathbf{1}$ to $\mathbf{8}$, compound $\mathbf{4}$ and $\mathbf{6}$ exhibited anti-bacterial and anti-fungal activity against all the tested human pathogens. All the coumarin triazole derivatives 1-8 showed excellent antifungal activity against $C$. tropicalis and $C$. krusei at a volume of $75 \mu \mathrm{L}$ which is comparable to that of standard viz., fluconazole. Within $6 \mathrm{~h}$, fluconazole showed activity against fungal pathogens, after $12 \mathrm{~h}$ fluconazole's activity was reduced against fungal pathogens. Triazolylcoumarins $\mathbf{4}$ and $\mathbf{6}$ exhibit good activity among the synthesized compounds due to the combined effect of coumarin and triazole, with phenolic and tetraethyleneglycol units, respectively. 
The structures of the compounds 1-8 were employed for docking studies with the target DNA gyrase B (PDB ID: 2Y3P). ${ }^{23}$ The ligands maintain an average four hydrogen bond with the DNA gyrase. 10-15 Poses were obtained for all the compounds and based on the top score selected for each compound. Among all the compounds, synthesized triazolylcoumarins $\mathbf{4 , 6}$ and $\mathbf{7}$ show high binding affinity towards the DNA gyrase B and the results are compared with simocyclinone (D8), which was also docked with the DNA gyrase using a similar protocol and the results are shown in table 2. Figure 2 shows hydrogen bonding and hydrophobic interactions of the triazolylcoumarins 1-8 with the DNA gyrase B, respectively and it has be seen that for each compound, the binding sites and their hydrogen bonding interactions vary.

The variation in the bioactivity is mainly due to the difference in the binding site. The activity study shows that triazolylcoumarins 1-8 shows comparable results with simocyclinone (D8) in the case of E. coli. It may be due to the fact that the binding sites of triazolylcoumarins are similar to that of the simocyclinone (D8) binding sites. The triazolylcoumarins $\mathbf{4 ,} \mathbf{6}$ and $\mathbf{7}$ show interaction with the key residues of the receptors Arg 91, Lys 42, Val 268, His 45, Arg 32, Gln 94 and Gln 114 with Glide energy of $-101.548 \mathrm{kcal} \mathrm{mol}^{-1},-101.002$

Table 2. Binding free energy docking simulation results of triazolylcoumarins 1-8.

\begin{tabular}{|c|c|c|c|c|}
\hline \multirow[b]{2}{*}{ Compounds } & \multirow[b]{2}{*}{ Glide Score } & \multirow[b]{2}{*}{ Glide Energy (kcal/mol) } & \multicolumn{2}{|c|}{ Hydrogen Bond } \\
\hline & & & D-H...A & Distance $(\AA)$ \\
\hline \multirow[t]{4}{*}{1} & \multirow[t]{4}{*}{-10.291} & \multirow[t]{4}{*}{-81.071} & Lys N-H. ...N & 3.19 \\
\hline & & & Lys N-H. . .O & 3.17 \\
\hline & & & Arg N-H. .. N & 3.07 \\
\hline & & & Gln N-H. .. O & 3.01 \\
\hline \multirow[t]{2}{*}{2} & \multirow{2}{*}{-8.963} & \multirow{2}{*}{-77.302} & Lys N-H. ..O & 3.29 \\
\hline & & & Ser O-H...O & 2.89 \\
\hline \multirow[t]{5}{*}{3} & \multirow[t]{5}{*}{-10.115} & \multirow[t]{5}{*}{-83.188} & Ser O-H. ..O & 3.26 \\
\hline & & & Ser N-H. ..O & 3.17 \\
\hline & & & Tyr N-H. ..O & 3.24 \\
\hline & & & Asn N-H. ..O & 3.30 \\
\hline & & & Gln N-H. . O & 3.06 \\
\hline \multirow[t]{5}{*}{4} & \multirow[t]{5}{*}{-10.238} & \multirow[t]{5}{*}{-101.548} & Arg N-H. ..O & 2.82 \\
\hline & & & Arg N-H. ..N & 3.13 \\
\hline & & & Arg N-H. . O & 2.98 \\
\hline & & & Lys N-H...O & 2.87 \\
\hline & & & Val O-H...O & 2.98 \\
\hline \multirow[t]{4}{*}{5} & \multirow[t]{4}{*}{-9.705} & \multirow[t]{4}{*}{-87.672} & Lys N-H. ...N & 3.31 \\
\hline & & & Lys N-H. .. O & 3.30 \\
\hline & & & His N-H...N & 3.01 \\
\hline & & & Gly N-H. ..O & 3.12 \\
\hline \multirow[t]{4}{*}{6} & \multirow[t]{4}{*}{-11.057} & \multirow[t]{4}{*}{-101.002} & Lys N-H. ...N & 3.05 \\
\hline & & & His N-H. ..N & 3.28 \\
\hline & & & Arg N-H. ..O & 3.07 \\
\hline & & & Gln N-H. ..O & 307 \\
\hline \multirow[t]{3}{*}{7} & \multirow[t]{3}{*}{-10.238} & \multirow[t]{3}{*}{-100.056} & Lys N-H. ..O & 3.06 \\
\hline & & & Gln N-H. . N & 3.21 \\
\hline & & & Arg N-H. .. O & 305 \\
\hline \multirow[t]{3}{*}{8} & \multirow[t]{3}{*}{-9.112} & \multirow[t]{3}{*}{-80.123} & Lys N-H. ..N & 3.13 \\
\hline & & & Ala N-H. .. O & 2.90 \\
\hline & & & Arg N-H. . . N & 3.07 \\
\hline Simicyclinone & -6.565 & -64.715 & Asp N-H. ..O & 3.30 \\
\hline & & & Arg N-H. .. O & 2.70 \\
\hline & & & Gln N-H. .O & 2.20 \\
\hline & & & Ala N-H. .. O & 2.70 \\
\hline & & & Ser N-H. ..O & 3.50 \\
\hline & & & Lys N-H. . O & 3.23 \\
\hline
\end{tabular}


1)
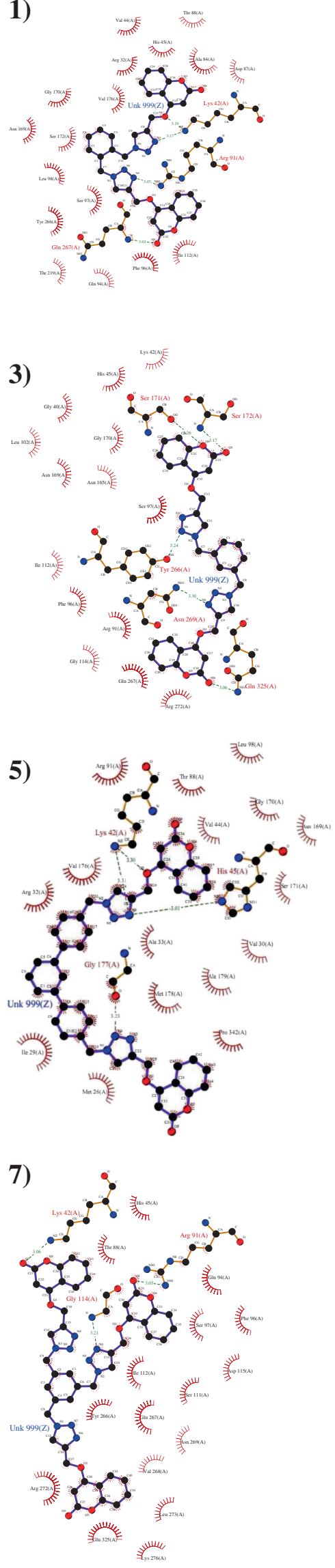

2)

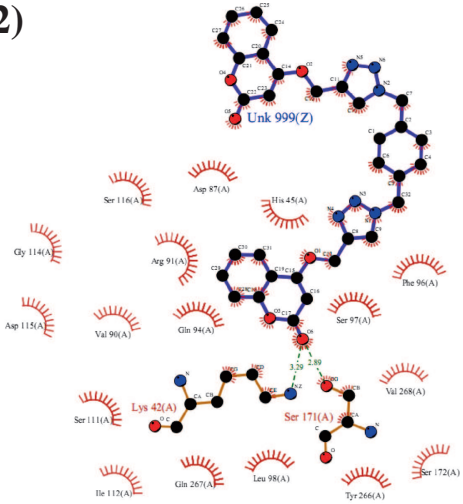

4)

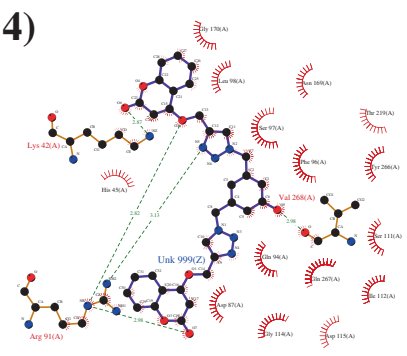

6)

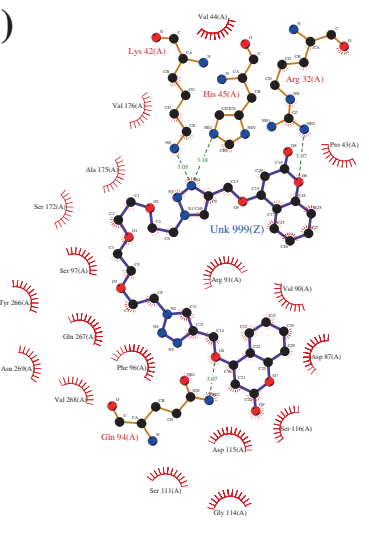

8)

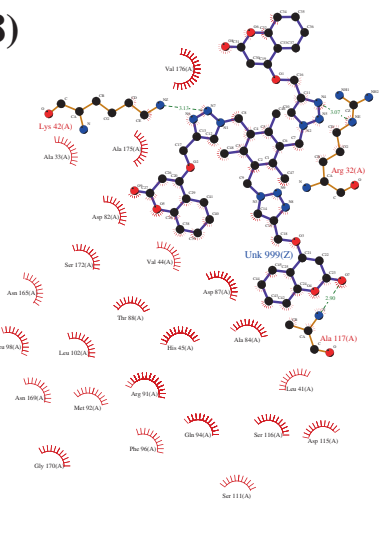

Figure 2. Interaction of triazolylcoumarins 1-8 with DNA gyrase B. 
Table 3. Theoretical ADMET properties of triazolylcoumarins 1-8.

\begin{tabular}{|c|c|c|c|c|c|}
\hline \multirow[b]{2}{*}{ Compounds } & \multirow[b]{2}{*}{$\mathrm{CNS}^{\mathrm{a}}$} & \multirow[b]{2}{*}{ SASA $^{\mathrm{b}}$} & \multicolumn{2}{|c|}{ Hydrogen Bonding } & \multirow[b]{2}{*}{$\mathrm{QP} \log \mathrm{S}^{\mathrm{c}}$} \\
\hline & & & Donor & Acceptor & \\
\hline 1 & -2 & 962.55 & 0 & 12 & -6.546 \\
\hline 2 & -2 & 970.04 & 0 & 11 & -7.212 \\
\hline 3 & -2 & 1010.42 & 0 & 11.5 & -7.715 \\
\hline 4 & -2 & 1023.68 & 1 & 12.25 & -8.206 \\
\hline 5 & -2 & 1187.89 & 0 & 11.5 & -10.753 \\
\hline 6 & -2 & 958.69 & 0 & 17.25 & -2.91 \\
\hline 7 & -2 & 1010.09 & 0 & 17.25 & -3.884 \\
\hline 8 & -2 & 1010.91 & 0 & 17.25 & -3.9 \\
\hline Tetracylcine & - & 641.47 & 2 & 7.5 & -4.53 \\
\hline Flucanacole & $+/-$ & 514.69 & 1 & 6 & -3.740 \\
\hline
\end{tabular}

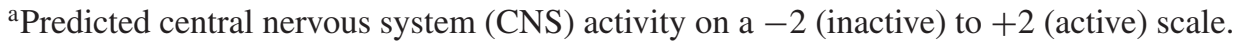

${ }^{\mathrm{b}}$ Total solvent accessible surface area (SASA) in square Angströms using a probe with a 1.4 A radius. ${ }^{c}$ Predicted aqueous solubility, $\log \mathrm{S}$. S. in moles/liter is the concentration of the solute in a saturated solution that is in equilibrium with the crystalline solid (QplogS).

$\mathrm{kcal} \mathrm{mol}^{-1}$ and $-100.056 \mathrm{kcal} \mathrm{mol}^{-1}$, respectively. The activity study clearly reveals that all the synthesized triazolylcoumarins 1-8 show excellent results comparable with that of simocyclinone (D8). Hence, the docking studies would of great help in the design of the novel triazolylcoumarins drug targets of bacterial proteins. Further, the theoretical prediction of the ADMET properties based on the numbers of hydrogen donors and acceptors have been studied for compounds 1-8 and the results are presented in table 3. The ADMET parameter shows that the reported triazolylcoumarins have good oral absorption and do not affect the central nervous systems (CNS) and hence could be favourable drug candidates after a systematic in vivo analysis.

\section{Conclusions}

We have synthesized a series of triazole based coumarin derivatives by the click chemistry approach. The antimicrobial activity showed that the coumarin derivatives 4 and 6 could be developed as potential antibacterial agents against $B$. subtilis, $S$. aureus, $K$. pneumonia, $P$. mirabilis and also anti-fungal agents against $C$. krusei and $C$. tropicalis. The molecular docking studies also revealed that compounds $\mathbf{4}$ and $\mathbf{6}$ may be good inhibitors of the DNA gyrase B enzyme and also showed strong hydrogen bonding with key residues of chain A of the enzyme dimer DNA gyrase B with novel binding conformation.

\section{Supplementary Information}

NMR and Mass data are available at www.ias.ac.in/ chemsci.

\section{Acknowledgements}

The authors thank the Council of Scientific and Industrial Research (CSIR), New Delhi, India for the financial support and the DST-FIST New Delhi, India for providing the NMR facility for the Department of Organic Chemistry, University of Madras, Guindy Campus, Chennai.

\section{References}

1. Riveiro M E, Moglioni A, Vazquez R, Gomez N, Facorro G, Piehl L, de Celis E, Shayo C and Davio C 2008 Bioorg. Med. Chem. 162665

2. Symth T, Ramachandran V N and Smyth W F 2009 Int. J. Antimicrob. Agents 33421

3. Shikishima Y, Takaishi Y, Honda G, Ito M, Takfda Y Kodzhimatov O K, Ashurmetov O and Lee K H 2001 Chem. Pharm. Bull. 49877

4. Kontogiorgis C A, Savvoglou K and Hadjipavlou-Litina D J 2006 J. Enzyme Inhib. Med. Chem. 2121

5. Yeh J Y, Coumar M S, Horng J T, Shiao H Y, Kuo F M Lee H L, Chen I C Chang C W Tang W F Tseng S N Chen C J Shih S R Hsu J T A Liao C C, Chao Y C, Hsieh H P 2010 J. Med. Chem. 531519

6. Kontogiorgis C A, Hadjipavlou-Litina D J 2005 J. Med. Chem. 486400

7. Lee Y, Lee S, Jin J and Yun-Choi H 2003 Arch. Pharmacal. Res. 26723

8. Grimm E, Brideau C, Chauret N, Chan C, Delorme D, Ducharme Y, Ethier D, Falgueyret J, Friesen R and Guay J 2006 Bioorg. Med. Chem. Lett. 162528

9. Fylaktakidou K, Hadjipavlou-Litina D, Litinas K and Nicolaides D 2004 Curr. Pharm. Des. 103813

10. Wu P, Feldman A K, Nugent A K, Hawker C J, Scheel A, Voit B, Pyun J, Frechet J M, Sharpless K B and Fokin V V 2004 Angew. Chem. Int. Ed. 433928

11. Himo F, Demko Z P, Noodleman L and Sharpless K B 2002 J. Am. Chem. Soc. 12412210

12. Demko Z P and Sharpless K B 2001 Org. Lett. 34091 
13. Howell L A, Howman A, O'Connell M A, Mueller A and Searcey M 2009 Bioorg. Med. Chem. Lett. 195880

14. Pericherla K, Khedar P, Khungar B and Kumar A 2012 Tetrahedron Lett. 536761

15. Liu X, Yang X, Fu Y, Zhu C and Cheng Y 2011 Tetrahedron 673181

16. Xue J L, He X P, Yang J W, Shi D T, Cheng C Y, Xie J, Chen G R and Chen K 2012 Carbohydr. Res. 36338

17. Kosiova I, Kovackova S and Kois P 2007 Tetrahedron 63312

18. Arjun P, Priya S M, Saranya Sivan P S, Krishnamoorthy M and Balasubramanian K 2012 J. Acad. Indus. Res. 115

19. Schrödinger Glide version 2009 LLC, New York, NY 18
20. Eldridge M D, Murray C W, Auton T R, Paolini G V and Mee R P 1997 J. Comput.- Aided Mol. Des. 2011

21. (a) Thomas $\mathrm{W}$ and Colin $\mathrm{K}$ http://www.gnuplot.info/ 2008; (b) Wallace A C, Laskowski R and Thornton J M 1995 LIGPLOT: Protein Engineering 8127

22. (a) Thomas J R, Liu X and Hergenrother P J 2005 J. Am. Chem. Soc. 127 12434; (b) Rajakumar P, Satheeshkumar C, Ravivarma M, Ganesan S and Maruthamuthu P 2013 J. Mater. Chem. A 113941

23. Edwards M J, Flatman R H, Mitchenall L A, Stevenson C E M, Le T B K, Clarke T A, Mckay A R, Fiedler H P, Buttner M J, Lawson D M and Maxwell A 2009 Science 3261415 